Arab World English Journal (AWEJ) Volume 12. Number4 December 2021

DOI: https://dx.doi.org/10.24093/awej/vol12no4.21

Pp.317-339

\title{
A Need for a Substantive Change in Tertiary EFL Education
}

\author{
Saeed Jameel Aburizaizah \\ The English Language Institute \\ King Abdulaziz University, Jeddah, Kingdom of Saudi Arabia \\ Email: saburizaizah@kau.edu.sa
}

Received: 8/14/2021 Accepted; 10/29/2021 Published: 12/15/2021

\begin{abstract}
As Saudi Arabia is increasing its international influence and educational collaboration at a global scale, promoting the importance of English language teaching and learning in basic and tertiary education has been more prioritized in the country. Diverse programs are offered in universities, incorporating foundation year programs and curricula, which have become a must for anyone passionate about his/her future, and a strategic necessity for any university that aims at preparing its graduates for their career life. This paper investigates the birth of one of the newest approaches in EFL curriculum design that tries to re-launch the link between labor markets and demands of academic requirements, global society, on the one hand, and the learners' needs on the other hand, and questions the opinions of foundation year students who completed one academic year of the newly launched curriculum in an English Language Institute at a Saudi public university, data collection employed a large-scale survey $(n=2000)$ that purposefully explores the students' opinion on the new curriculum. Results obtained from 371 respondents reveal students' satisfaction toward a clear improvement in their language skills, specifically presentation, vocabulary, and writing, and joint agreement that the course was autonomy supportive. It was also significant that the course increased the students' intrinsic motivation and appreciation of the challenges and inspiration this curriculum had given to them. This paper is an extended piece of knowledge for further research. It provides an illustration of students' deep thoughts on their target language needs for policymakers and curriculum designers to consider.
\end{abstract}

Keywords: autonomy, curriculum, eclectic, tertiary EFL, outcomes, survey, syllabus

Cite as: Aburizaizah, S. J. (2021). A Need for a Substantive Change in Tertiary EFL Education. Arab World English Journal, 12 (4) 317-339.

DOI: https://dx.doi.org/10.24093/awej/vol12no4.21 


\section{Introduction}

In the Saudi higher education system, textbooks function as the main components of the English curriculum for foundation year students. Selected authorized foreign publishers, who possesses a ready-made systematic syllabus for language instructors to follow, usually design books and readers. Such one-size-fits-all books and texts shape the curriculum and lead to more competitive publishers who continue to pursue more space in providing adequate language educational materials.

With the dominant business of publishers of English textbooks, local EFL curriculum development is an area of research that has not been given sufficient attention in the Saudi higher education and specifically in English education for foundation year programs in many public universities. Such practices urge us, as discussed by Tanaka (2012), to examine the curriculum development approaches and reexamine how teachers in the language education field perform their roles whether they transmit curriculum, develop curriculum, or make curriculum. He also illustrated that some tertiary institutions usually outsource their English programs to special schools and bodies, creating a perception that EFL education is not a built-in component of university education or it is strictly specialized and hard to design by internal bodies. More questions arise such as: does the designed curriculum meet students' needs? Does it meet labor demands and the ambition of academic departments? Are we convinced of the one-size-fits-all textbooks which the publishers compete to provide? Are decision-makers and curriculum leaders still at a muddy point where no profound comprehension of the difference between curriculum and textbooks? What objectives foundation year English programs should uphold? And finally, as questioned by Tanaka (2012), which are the best approaches to curriculum and instructional design that will produce English language proficient users who can fulfill their needs of communication in a globally changing world.

Curriculum development/improvement is no longer a solo process of executing that curriculum, but as elaborated by Snyder, Bolin \& Zumwalt (1992), "a process of growth for teachers and students, a change in thinking and practice" (p.428). The teacher plays many roles throughout the process of creating the curriculum such as utilizing supplementary materials, creating and renovating new parts of the curriculum. The creative "enactment" approach also argued by the two researchers in which teachers and their students share their roles in creating their curriculum.

\section{Research question}

The main research question for this paper lies at the core of investigating the students' opinion on the newly launched curriculum in an English Language Institute at a Saudi public university. As such, the primary interrogation of this paper is explored with the support of several sub-questions that cover areas such as rating the student's progress, rating the most improved skills, rating the most skills that need improvement, rating which skills are the easiest, rating which skills are the most difficult, illustrating the distinctive features of the new curriculum, describing the overall experience, and recommendations. 


\section{Research significance}

This paper is intended to provide a better view of preparing global citizens of the future in Saudi Arabia to master communicative competence in the $21^{\text {st }}$ century through English programs offered in universities foundation year tracks. With a description of the newly launched and implemented curriculum as the EFL program for foundation year students at the English Language Institute of a Saudi public tertiary institution, this paper explores the students' opinion on their experience throughout the academic year they spent in studying English. Although it is unknown what results in a similar exploration conducted previously, the survey results in this paper with its examination of the syllabus for the newly launched foundation year EFL course show a fantasitc diversity and thoughtful concerns among students in how EFL is taught and learned.

\section{Literature Review}

There are growing demands for accountability in public life, with education a particularly urgent case and foreign language education a prime example within it (Long, 2005). The majority of foundation year university students with academic, occupational, and survival needs for second language competency, functional L2 proficiency, as well as academic departments, are usually dissatisfied with language programs and instructional practices that are irrelevant to those needs. In contrast, all courses and programs of all kinds and areas must be relevant to the students' needs and outer world behind classroom walls. Instead of a one-size-fits-all curriculum, it is urgent and demanding to look at language programs as programs that are designed for particular purposes for particular people in specific contexts.

EFL Curriculum design and development approaches depend on many theories and principles. However, significant components of curriculum development remain crucial and inevitable such as needs and environment analysis, principles, goals, sequencing, presentation model, assessment, evaluation, and synchronized professional development. As described by Macalister and Nation (2019), the plans of a course mainly direct the needs analysis. It examines what the learners know already and what they need to know. For decades, educators and researchers have argued that the basic approach to education strives to meet unique and fundamental human needs and develop human potential (Patterson, 2003). For example, William Glasser (1990), creator of choice theory and Quality Schools, has maintained that we will not have more motivated students who work harder and learn more, nor will we have lower dropout rates until we create more need-satisfying schools. Needs analysis is a process of assessment and thus can be validated by examining its reliability, validity, and practicality and assuring that the course will contain authentic and valuable things to learn. When reaching principles, Macalister and Nation (2019) mentioned that they must be general enough to allow variety and flexibility in their application to suit the wide range of conditions in which language is taught. Such principles cover curriculum sequencing, presentation model, assessment, and evaluation. With all such principles, it is now entirely clear that teaching grammar and random vocabulary is no longer a sufficient practice. Elaborated by Finney (2002), language is a tool for communication. In that sense, we need must design classes that prepare students to become effective communicators and users of the language in many meaningful and varied contexts. Learners nowadays are urged to learn how to learn and maintain continuous learning dispositions where learner-centered model and facilitation of accepting change prevail in rapidly changing and innovative educational systems. Curriculum development from the side of teachers identifies other perspectives. As described by Sulaiman, Ayub, and Sulaiman (2015), "implementing the new curriculum could be 
difficult and may take time because educational leaders need to convince the teachers to accept the curriculum and implement it as intended" (p.495). Curriculum implementation is a change process. Part of the change requires teachers to acquire new knowledge about the curriculum; however, mastering the new knowledge is not the only requirement for teachers to change (Ornstein \& Hunkins, 2014).

Facets of rapid, and demanding changes in education are the inclusion of thinking and presentation skills in curricula. Many research indicates that the traditional way of teaching does not support teachers in promoting thinking skills (Ennis, 1990; Swartz \& Perkins, 1989; Haynes, 2002) and since these skills require openness, autonomy, and reflection on learning (Wilson \& Murdoch, 2008), the materials provided should encourage these qualities in the learner (Shirkhani \& Fahim, 2011). With regard to presentation (speaking) skills, it is commonly unpleasant that the high school English curriculum puts too much emphasis on official tests (university admission tests at the expense of communication skills. Presentation skills are essential for students in tertiary education, however, and due to the fact that most students focus on final exams and also due to the crowded nature of classrooms in the past, presentation skills have been the least tackled language proficiency skill. Many factors that contribute to students' reluctancy towards playing active roles in speaking activities, such as a study by Gaudart (1992) where he claimed that some teachers attribute learners' passiveness in the classroom discussions to lack of motivation.

Amirian and Tavakoli (2016) have indicated that while acessible speaking and presentation are so significant in study contexts, many learners in tertiary contexts avoid speaking and presenting because of their low self-efficacy. Two modes of Bandura's (1995), examined by the two authors. They conducted a self-efficacy comparison during presentations in English among two groups of EFL learners and non-EFL learners. They also managed to explore the relationship between these two constructs. With the results they obtained, university curricula must include more presentation-based activities and tasks. Another more recent study provided by Barrett, Liu and Wang (2020), and concerned with seamless learning for oral presentations reveals an obvious need among students for more training on related to language production such as designing expressions, language structures, and body language to enhance their performance. While focusing on the importance of thinking and presentation skills in EFL curricula, numerous research and curriculum development plans have emphasized the demanding needs and advantages of teaching each primary language skill comprehensively, and these skills include listening, reading, speaking, and writing along with the significant structure knowledge gained from grammar and vocabulary.

\section{Methodology}

\section{Context}

The concerned English Language Institute of this paper has been established in the academic year 2010/2011. It seeks to be a renowned and respected center of academic and educational excellence that performs its mission and educational role in a manner befitting its host university. The Institute programs are open to all foundation year students. They raise their level of English language proficiency to facilitate their subsequent academic careers within the various university specializations and, with its newly developed curriculum, provide learners with enriching courses in language that develop their communication and thinking skills. 


\section{Participants}

While qualified faculty trained explicitly in language instruction have been leading the program, the participants' community of this paper represent the enrolled students who reflect a student body primarily consists of high school graduates entirely from the local province. The number of newly admitted full-time students during the launching of the new curriculum varies depending on seat availability at the university. Data for this paper has come from around 1000 students at the women's campus, and 1,000-1,500 at the men's campus, with a total number of 370 students from the two campuses responding to the research tool. Participants who participated and were admitted into the university were required to sit for a placement test to begin the English course. However, students who earned a band score of 5.5 on the IELTS exam or a 59 on the internet-based TOEFL (IBT) are eligible for exemption from enrolling in the English program.

\section{Research Tools}

The current descriptive study grounds its argument based upon the theoretical notions of a quantitative/qualitative research paradigm. The newly developed EFL curriculum consists of a syllabus that follows 14-week course pacing guides delivered to foundation year students (males and females) as part of their EFL program at the university. With a general aim towards measuring the influence of this curriculum on students' learning, a two-fold survey was structured and distributed online to students consisting of 9 questions (six closed-ended and three open-ended) as follows:

- Rate your progress from one to 10 ?

- Which skill has most improved?

- Which skill do you think you still need to improve?

- Which skill is the easiest in the ELI program?

- Which skill is the most difficult?

- Describe the change in your level before and after studying at the ELI?

- What makes the new curriculum distinctive?

- What recommendations and suggestions do you offer to enhance the new curriculum in the future?

- Summarize your experience throughout your study of this curriculum.

\section{The Curriculum}

The new curriculum adopts a backward design, as described by Richards (2013), in which detailed learning outcomes mark the beginning of the developed curriculum, then followed by selecting the teaching methods and syllabus design. The Common European Framework of Reference (CEFR) is a recent example of backward design.

The intensive English language course is a required course in the Foundation Year Program. The course design provides language instruction beginning at a B1 level on the Common European Framework of Reference for Languages (CEFR) and exiting at C1 level, which is within the band of being an independent user. These CEFR levels corresponded with a range of 4-6 on Canadian Language Benchmarks and are marked as an intermediate proficiency level. The program, led by qualified faculty trained explicitly in language instruction. Enrollment of students reflects a student body that primarily consists of high school graduates almost entirely come from the local province. The number of newly admitted full-time students during 
the launching of the new curriculum varies depending on seat availability at the university. Still, they were around 1000 students at the women's campus and 1,000-1,500 at the men's campus. Students admitted into the university must sit for a placement test to begin the English course. However, students who earned a band score of 5.5 on the IELTS exam or a 59 on the internetbased TOEFL (IBT) are eligible for exemption from enrolling in the English program

The course at the Institute targets the development of the person as a whole using a curriculum and instructional methods that are argued and named by Professor Brown (1995) as an "eclectic approach". He illustrated how language program developers could choose among multiple contents and instructional strategies that are better designed and customized according to specific students in specific situations so that each learner - as a whole - is treated as a unique person. He also claims that approaching curriculum through this eclectic method guarantees more freedom and flexibility to instructors to design their pedagogical practices around the needs and levels of their students. The diverse classroom instruction-focuses on eight core areas of language skills, as illustrated in table one.

Table 1. Core skill areas

\begin{tabular}{|c|l|}
\hline \multirow{2}{*}{ Strands of Language Learning } & \multicolumn{1}{|c|}{ Relevant Skills } \\
\hline \multirow{2}{*}{ Meaning-Focused Output } & Listening \\
\cline { 2 - 2 } & Reading \\
\hline \multirow{2}{*}{ Fluency Development } & Speaking \\
\cline { 2 - 2 } & Writing \\
\hline \multirow{2}{*}{ Language-Focused Learning } & Presentation skills \\
\cline { 2 - 2 } & Thinking skills on familiar language \\
\hline
\end{tabular}

Note 1. Adopted from Nation (1996, p. 7)

These eight areas organize and focus the goals, content, and learning outcomes (SLOs). They coherently build skills from level one to level two. Furthermore, the program provides an extended educational experience that targets the 5.5 bands in the IELTS.

\section{Curriculum Plan}

When the Institute created the curriculum development plan, it aimed to be relevant to the students' minds and around a broad spectrum of up-to-date and authentic contexts. A needs analysis conducted on all campuses of the Institute in order to identify the reasons why many students who are enrolled in the foundation year fail academically even after studying in intensive classes of English. Several procedures, mainly interviews, observations, and questionnaires, were used to gather information about the needs of the students and desired to learn outcomes. The course learning outcomes of English skills tried to respond to what is known as students' areas of most significant difficulty and greatest needs and lacks. Leaders of academic departments participated in interviews to determine significant skills that students lack when they pursue their academic degrees. A variety of learning outcomes that were drawn primarily from trusted benchmarks makers and frameworks, were used. The course is constructed successfully in helping students learn how to communicate more effectively and functionally in a variety of settings of various topics. 
On that basis, the Institute had built its approach to the English program. The Institute adopted policies and approaches to connect students and teachers to the broader contexts and situations such as functional use of the language, encouraging students to engage in different modes of communication culture and societies, thus leading students to produce meaningful output and embark meaning negotiation and looking at the outer world from different perspectives. The ELI curriculum has two levels coded as 110 and 120. Level 110 aims to develop student language proficiency beginning at a B1 level on the Common European Framework (CEFR), moving into the B2 level on the CEFR, within the band of an independent user. The main objective of level 120 is to expand student language aptitude, moving from B2 level on the CEFR to $\mathrm{C} 1$ level. The students will acquire the necessary learning strategies along with critical thinking skills, presentations skills, and sub-skills. Students could develop the essential learning techniques to take part in deliberations and discourse with classmates. Hence, the students will build confidence for independent learning throughout their university career. Table two illustrates the program structure .

Table 2. Course structure

\begin{tabular}{|l|l|}
\hline ELI_110 & (CEFR-B1-B2) $=($ CLB 4-5) \\
\hline Program level & 14 weeks \\
\hline Weeks per level & 3 hrs \\
\hline Credit Hours & 18 \\
\hline Contact Hours/week & 4 per week \\
\hline Online hours & CEFR (B1) CLB (1-2-3) \\
\hline Entry level & B2 IELTS 5 \\
\hline Exit level & $100 \%$ \\
\hline Course value & Level-by-level pass/fail policy (60 points) \\
\hline Pass score & \\
\hline ELI_120 & (CEFR-B2-C1) $=$ (CLB-.5-6) \\
\hline Program levels & 14 weeks \\
\hline Weeks per level & 3 hours \\
\hline Credit Hours & 18 \\
\hline Contact Hours/week & 4 per week \\
\hline Online hours & CEFR (B2) CLB (1-2-3) \\
\hline Entry level & C1 - IELTS 5.5 \\
\hline Exit level & $100 \%$ \\
\hline Course value & Level-by-level pass/fail policy (60 points) \\
\hline Pass score &
\end{tabular}

The ELI courses syllabus is based on selected themes: Community, Academics, and Employment and Business. These themes are designed thoroughly through examining related topics. These topics are chosen extensively along with lists of vocabulary, as derived from the CEFR B1-C1, IELTS, function as critical factors in students' ability to receive and produce the language for each designed course level. Based on a blended approach, thinking skills, presentations skills, and sub-skills are infused within all aspects of the curriculum to develop well-rounded students. Tables three and four in Appendices A \& B illustrate samples of weekly pacing guides .

The learning objectives included in the pacing guides give teachers the privilege of selecting the materials and teaching methods that are most suitable for helping them to meet their learners' needs. In addition, the semi-structured nature of the model means that the curriculum 
provides teachers with only general guidelines on how to structure their classes. The lesson plan models (syllabus guide in tables three and four in Appendices A and B) encourage teachers to clarify the goals of particular lessons to their learners at the beginning of each session. In addition, teachers include tasks in their lesson plans and design activities that will lead their students and assess how much of the outcomes their students had achieved.

\section{Findings}

While 370 students from the two campuses participated in the survey, the percentage of male responses was slightly higher (52\%) than that of female participants (47.83\%), as illustrated in figure one.

\section{campus}

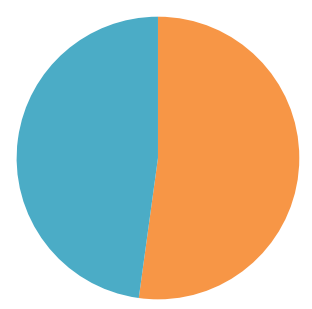

Men campus

Women's Campus 1

Figure 1. Campuses participants

Part 1. Closed-Ended Survey Questions

Progress in English Attainments

The students rated their progress in English based on a scale of zero to ten. Most students' answers were in the middle of the scale, with a tendency toward big improvement. However, the percentages of those at the extreme ends of the scale were also relatively high (16\% selected minimal progress, and $11 \%$ chose significant progress), as illustrated in figure two.

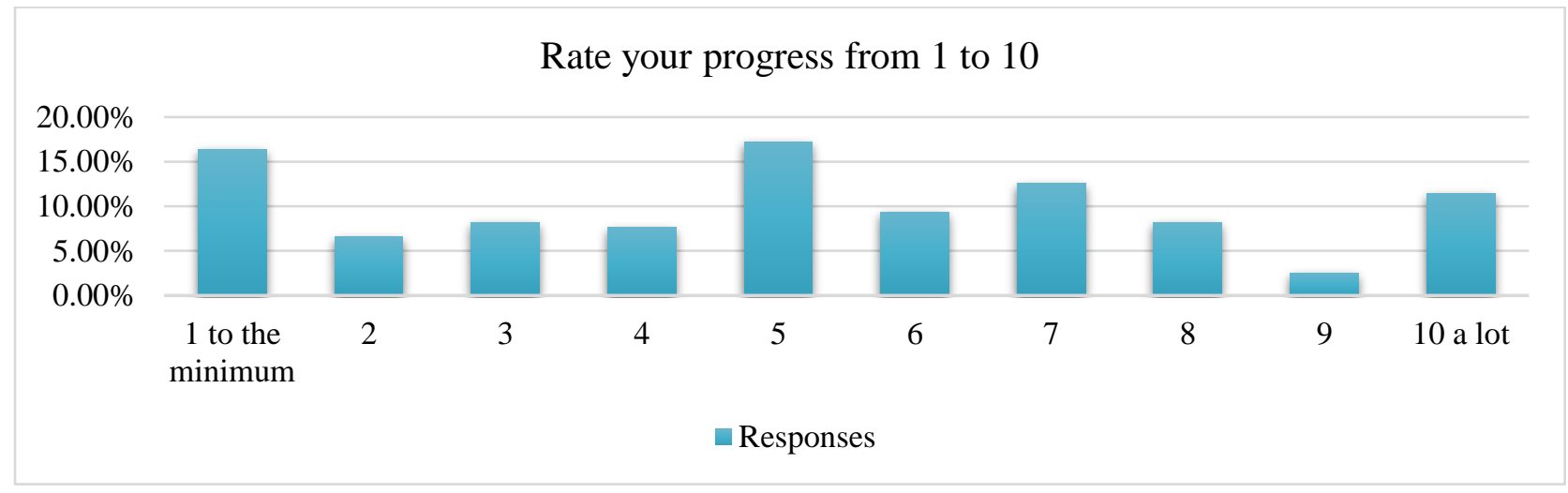

Figure 2. Progress rate among students 
In another similar description illustrated in figure (3), students evaluated the improvement in their level of language ability after the English program. The majority (40\%) said their level had improved, and 15\% said their level had significantly improved.

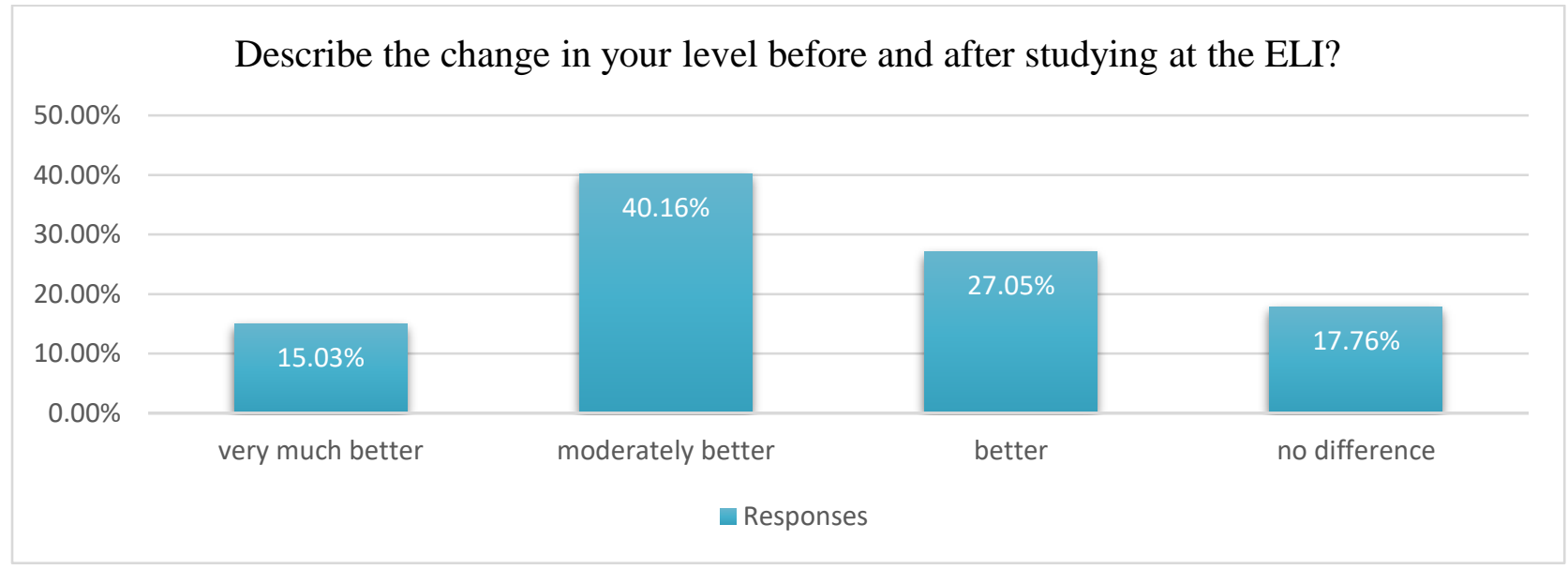

Figure 3. Change in proficiency level before and after

The data obtained from the survey also showed that most students had experienced some improvement while studying at the ELI. However, the level of improvement among the students varied significantly. That can be attributed to two factors: the first factor is the variation in the students' level of language ability and preparation due to an unreliable placement test and previous preparation they received at their high schools. The second factor is related to the teaching and learning environment, including teaching quality and the campus on which the student was studying. It was, therefore, important to examine the data of both male and female students, focusing on the improvement, in each individual skill, to determine whether there were any possible effect of gender.

More analysis of the obtained data indicated that there was a variation in opinions between students studying in different learning environments that were related to gender. Female students indicated that their level of English had significantly improved. Learners' dispositions in language education are usually affected by several factors, as argued by Ortega (2009). She concluded that gender is one main factor that affects the duration and how a learner learns and processes a language. Other research has discussed the impact and difference of gender on second language acquisition and attainment and why these differences exist. Some differences are related to brain functions and nature. An interesting research-based proved argument by Dionne, Dale, Boivin, and Plomin (2003) indicates that the female mind is more arranged for language gaining indeed from birth.

Other differences that appear in a study by Mahmud (2018), indicate sex-based grouping (female-sex group, male-sex group, and mixed-sex group). Other studies such as one by GĹ, Ăłwka (2014) supported female outperformance in language learning due to their openness and readiness to use new linguistic structures, thus aligned with the socio-linguistic approach by Ellis (2012). 
The results in this current paper revealed that the percentage of females who said that they have improved is higher by $20 \%$ than males. The percentage of female students who indicated no improvement was low (12\% of the female population) in comparison with the percentage of male students who reported they had not experienced any improvement (20\% of the male population) as illustrated in figures four and five.

How do you describe your progress after studying at the ELI? (Females)

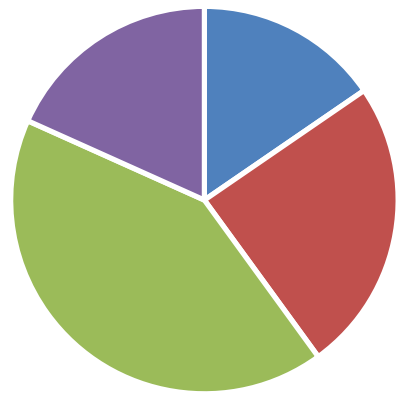

- no difference $(n=27) \quad$ little better $(n=43) \quad$ average $(n=73) \quad$ much better $(n=32)$

Figure 4. Rating progress in English among female students

How do you describe your progress after studying at the ELI? (Males)

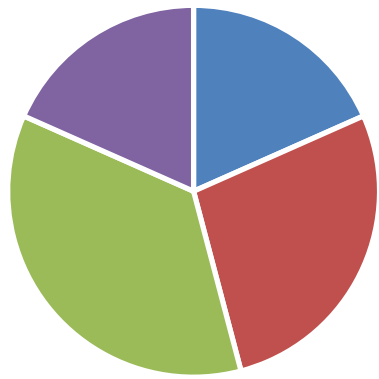

no difference $(n=38) \quad$ little better $(n=57)$ average $(n=74) \quad$ much better $(n=38)$

Figure 5. Rating progress in English among male students

\section{Skills Assessment}

The survey asked the students about their level of improvement related to the following language skills: presentation, listening, reading, writing, grammar, and vocabulary. The new curriculum help learners develop the academic skills they needed to pursue their academic degrees. With this in mind, presentation, reading, and writing skills are emphasized more than listening and grammar skills. The data showed that the presentation skill was the skill that had improved the most, with the vocabulary skill coming second and the writing skill being the third 
most improved skill. Grammar and then reading were the skills that had improved the least, as illustrated in figure six.

\section{Which skill has most improved?}

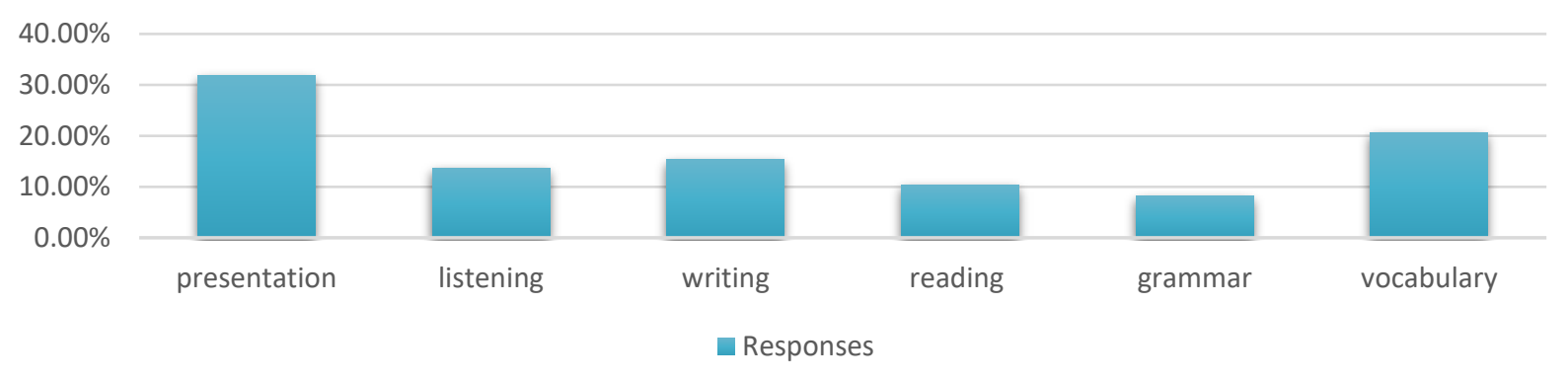

Figure 6. The most improved skill

Since reading was one of the main focuses of the curriculum objectives, it was surprising that there was slight improvement in reading skills. The indication that there were significant improvements in presentation, vocabulary building, and writing skills is clear since the curriculum objectives prioritized these skills.

When students selected the skills which they thought as the most skills that need development, the majority put grammar first in rank, then writing, followed by the presentation. Vocabulary, reading, and listening were the skills the students chose as the least in need of development, as illustrated in figure seven below.

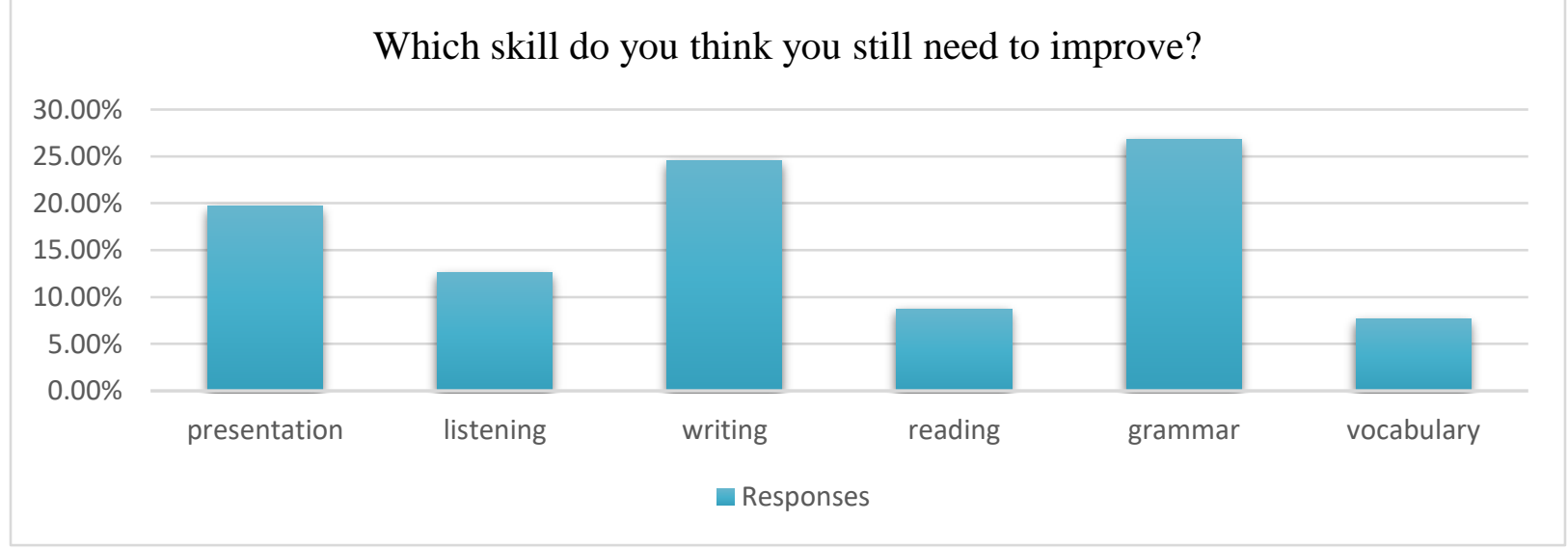

Figure 7. Skills that still need improvement

Such expected results with this communicative curriculum that focuses on task-based and active learning, it is clear that students see the curriculum as new in a Saudi context. Saudi students are used to traditional teaching ways, with the grammar-translation method being the dominant ESL teaching approach (Aburizaizah, 2013). This finding reveals that the students were aware of the importance of presentation, vocabulary building, and writing in English to 
their success in their preparatory program. They are aware of the 21 st-century skills. However, not aware of required reading in their following studies after exiting the preparation year.

Students' disposition towards selecting and customizing specific learning strategies is strongly impacted by some beliefs about learning a language. These learners have varied perceptions on what makes language learning practical and successful. Ellis (2008) discussed that some learners perceive the target language structure and vocabulary are two essential skills. However, some learners think that using the target language to produce meaningful output in certain situations and contexts is more important. In a needs analysis study carried out by Aburizaizah (2013), results reveal expressive skills were the most critical skills for students' success in the preparatory year program.

The finding that the students considered the skill of reading to be not only the least essential skill but also the one that had improved the least contradicts the curriculum objectives, which state that reading is essential for students. This fact raises questions about the reading content of the new curriculum and the teaching methods used in classrooms. Reading comprehension is considered a difficult skill for learners with limited vocabulary. The reading materials included in the curriculum need to be revised to check their appropriateness for their level of ability. It is also essential to check on how teachers teach reading: are they implementing different reading strategies to develop student's comprehension, or is the focus on vocabulary memorization, for instance?

Additionally, exciting results are worth mentioning here about an obvious similarity in the opinions of male and female students as they ranked the language skills. Responses from both female and male students to the question related to the most improved skills and the skills that required the most improvement were similar, as illustrated in figures eight and nine. The presentation skill, remarkably, was the most improved skill, and enhancements in vocabulary building were high too. Moreover, both groups agreed that grammar and reading were the least necessary skills. Writing seems to have been essential for the male students, but not for females. All the students agreed that regarding the need for improvement, the skills should be listed in the following order: presentation, writing, vocabulary, and grammar.

Which skill has most improved? (Males)

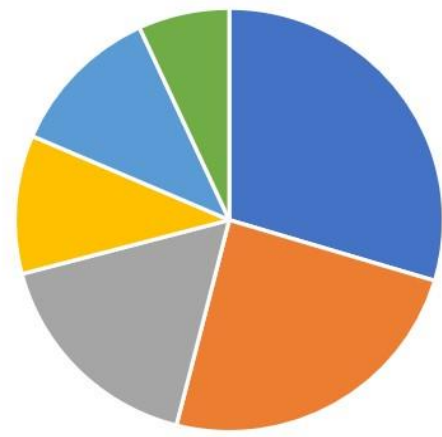

- Pres ( $n=56)$

voc $(n=46)$

- listening $(\mathrm{n}=32)$

arammar $(n=20)=$ writing $(n=22)=\operatorname{reading}(n=13)$
Which skill has most improved? (Females)

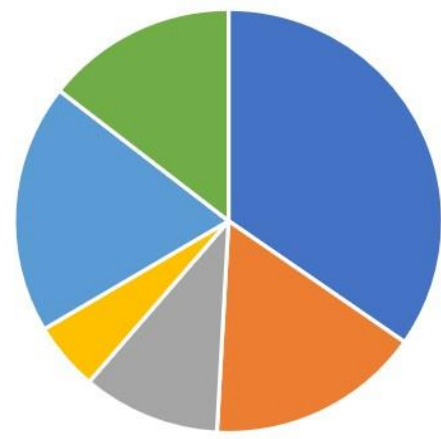

- Pres $(n=60) \quad \operatorname{voc}(n=28)$

- listening $(\mathrm{n}=18)$

grammar $(n=9) \approx$ writing $(n=33) \backsim$ reading $(n=25)$ 
Arab World English Journal (AWEJ) Volume 12. Number 4. December 2021

A Need for a Substantive Change in Tertiary EFL Education

Aburizaizah

Figure 8. Males and females' similarities in rating the most improved skills
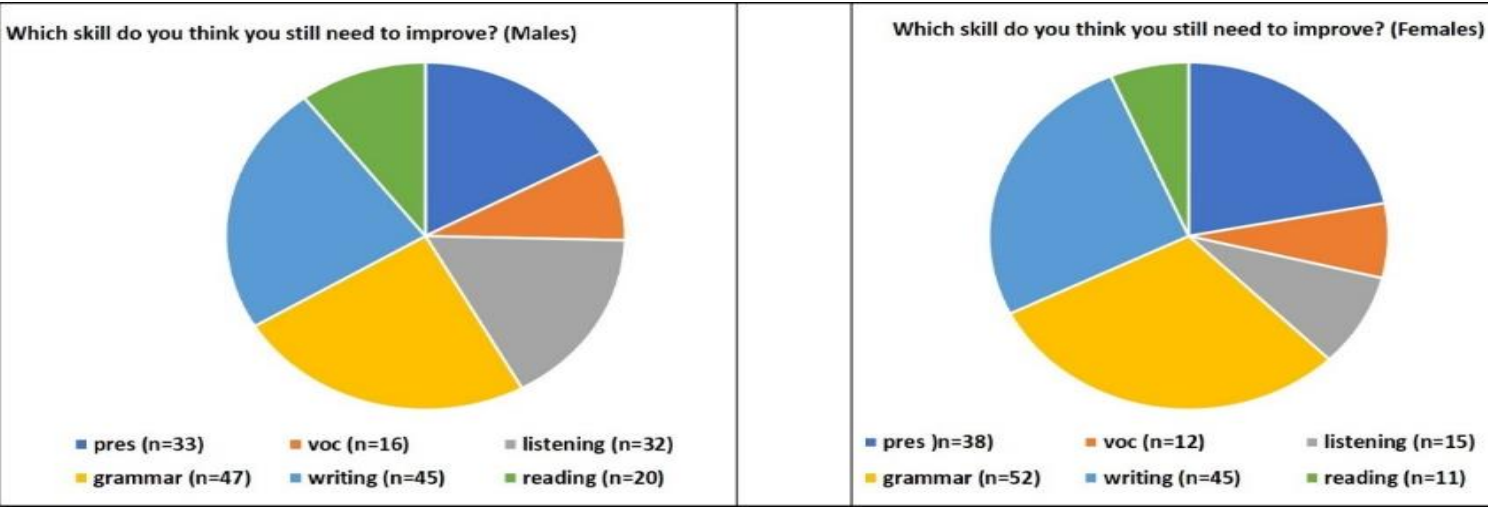

Figure 9. Males and females' similarities in rating skills that need improvement

These findings are significant since it reveals that the goals of the new curriculum were accepted by both groups of students equally, regardless of environmental differences or the classroom learning experiences each student had had.

When students expressed their opinion on most challenging and most manageable language skills, their answers showed that presentation and writing skills were the most difficult skills to learn, as illustrated in figures (10) and (11).

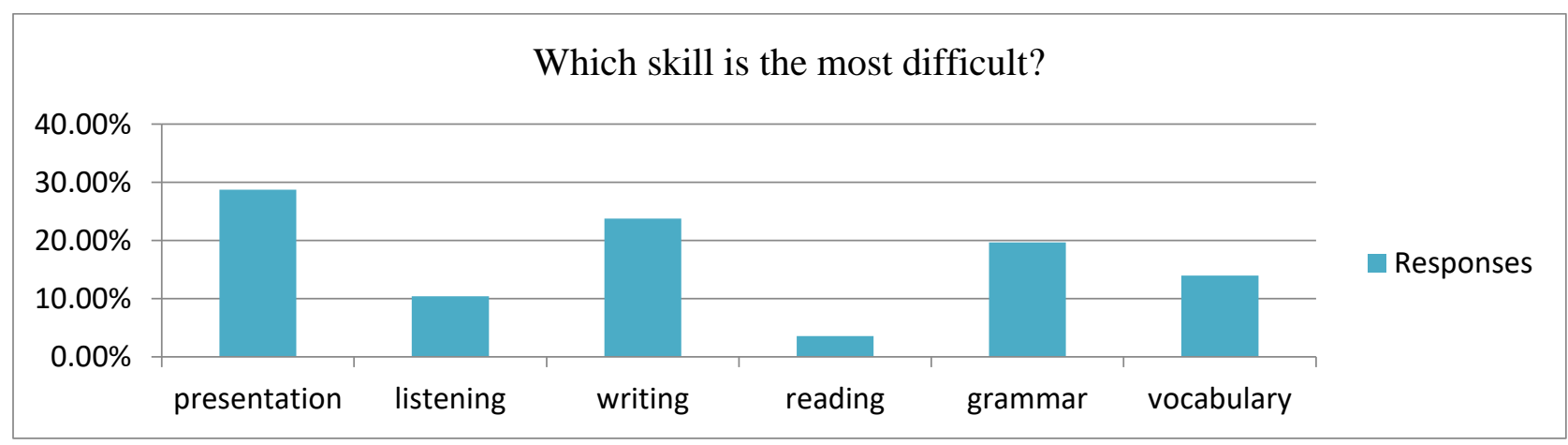

Figure 10. The most difficult skills

Which skill is the easiest in the ELI program?

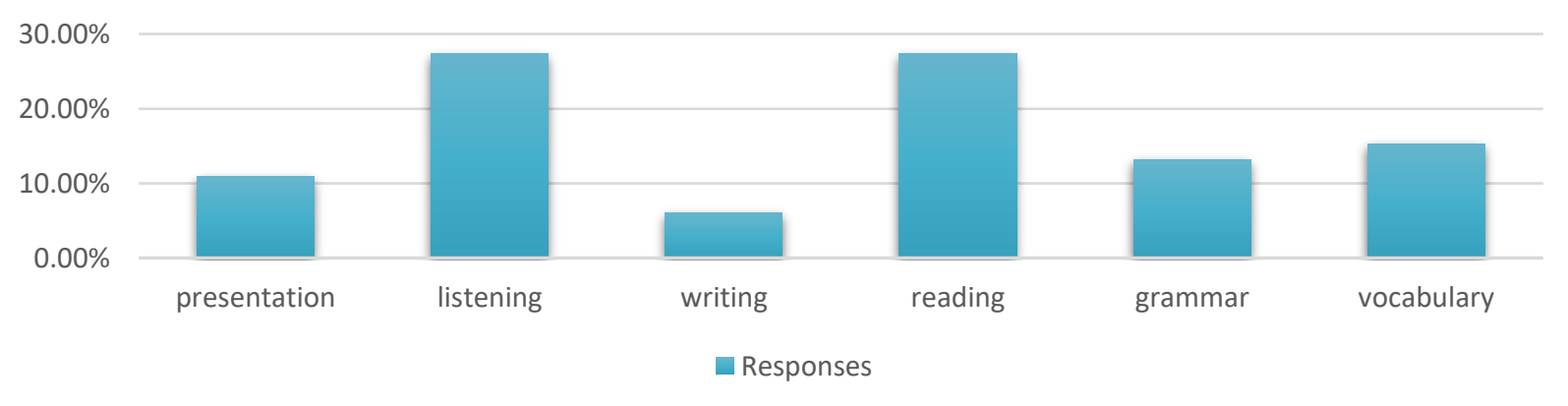


Figure 11. The easiest skills

Grammar and vocabulary skills were next in difficulty. These findings indicate that productive skills constitute a challenge for the students, whereas they considered receptive skills - listening and reading - the most effortless skills to learn. According to many studies, learners tend to develop their receptive skills before acquiring productive capability, and this is related to the cognitive approach where cognitive learning is about creating proper understanding and is a way of learning that helps the learners to use their brains more effectively (Sreena \& Ilankumaran, 2018), thus reading and listening increase students' comprehension which boosts their ability to speak and write. During their basic education years, Saudi students are taught English through traditional methods, which focus on the memorization of grammatical structures and vocabulary rather than on the practical use of the language.

\section{Part 2. Open-Ended Survey Questions}

In the open-ended questions, the participants clarified their areas of satisfaction and dissatisfaction toward the new curriculum. Two hundred and forty-five students responded to the questions in this section. Answers from participants presents four categories named as $(\mathrm{C} 1$ : areas of unsatisfaction, C2: teachers, C3: content and skills, C4: program structure), as illustrated in a table (Table 5). Students' opinions were clear in extracts from their responses. The most interesting suggestions put forward by the students proceed later in this document.

Table 5. Areas of satisfaction and dissatisfaction towards the new curriculum

\begin{tabular}{|c|c|c|c|}
\hline C1. Areas of dissatisfaction & C2. Teachers & C3. Content and Skills & C4. Program Structure \\
\hline $\begin{array}{l}\text { Go back to the previous } \\
\text { curriculum. }\end{array}$ & Teachers were helpful. & $\begin{array}{l}\text { Very challenging, } \\
\text { materials make you } \\
\text { work harder. }\end{array}$ & $\begin{array}{l}\text { The program makes } \\
\text { you depend more on } \\
\text { yourself to learn. }\end{array}$ \\
\hline No clear goals. & $\begin{array}{l}\text { The teacher made it very } \\
\text { easy. }\end{array}$ & $\begin{array}{l}\text { Presentation helped me } \\
\text { to practice the } \\
\text { language. }\end{array}$ & $\begin{array}{l}\text { Not too many exams as } \\
\text { in previous year, every } \\
\text { three weeks, there is } \\
\text { more time for practice } \\
\text { before exams. }\end{array}$ \\
\hline $\begin{array}{l}\text { Not organized, too much paper } \\
\text { printing because there were no } \\
\text { reference books. }\end{array}$ & $\begin{array}{l}\text { Teachers and } \\
\text { administrators have good } \\
\text { attitude. }\end{array}$ & $\begin{array}{l}\text { Variety of topics and } \\
\text { activities are related to } \\
\text { everyday life matters. }\end{array}$ & $\begin{array}{l}\text { No book, there is } \\
\text { flexibility in term } \\
\text { activities. }\end{array}$ \\
\hline $\begin{array}{l}\text { A lot of work and no campus } \\
\text { library. }\end{array}$ & $\begin{array}{l}\text { Arabic-speaking teachers } \\
\text { helped us to understand } \\
\text { grammar skills. }\end{array}$ & A lot of new VOC. & $\begin{array}{l}\text { It has clarity, structure, } \\
\text { and punctuality. }\end{array}$ \\
\hline Tough and extended class hours. & $\begin{array}{l}\text { Native English language } \\
\text { teachers helped to } \\
\text { improve my spoken } \\
\text { English when talking to } \\
\text { them. }\end{array}$ & The final project. & $\begin{array}{l}\text { The extended class } \\
\text { hours forced us to } \\
\text { practice more. }\end{array}$ \\
\hline Level one was very hard. & $\begin{array}{l}\text { Teachers encouraged } \\
\text { group work where weak } \\
\text { students learn from } \\
\text { strong ones. }\end{array}$ & & $\begin{array}{l}\text { It focuses on one skill } \\
\text { every day. }\end{array}$ \\
\hline \multicolumn{4}{|l|}{$\begin{array}{l}\text { Assessment questions were not } \\
\text { from the curriculum. }\end{array}$} \\
\hline Not enough focus on grammar. & & & \\
\hline
\end{tabular}




\begin{tabular}{|l|l|l|l|}
\hline $\begin{array}{l}\text { Project needs to be clear. More } \\
\text { time should be given to complete } \\
\text { it. }\end{array}$ & & & \\
\hline $\begin{array}{l}\text { The same teacher and same } \\
\text { classroom for the whole semester } \\
\text { was boring. }\end{array}$ & & & \\
\hline Very rigorous system. & & & \\
\hline $\begin{array}{l}\text { Goals, assessment methods, and } \\
\text { teaching materials were not } \\
\text { explained from the beginning of } \\
\text { the year. }\end{array}$ & & & \\
\hline
\end{tabular}

\section{Students' Suggestions for Future Curriculum Development}

Unexpectedly, a high number of students gave comprehensive and detailed recommendations; there was a consensus among students on some issues mentioned in their recommendations. Out of those students who gave recommendations, most proposed that the ELI should use a course book, because it is easier for students to follow and prepare for the test. Even with the online and printed materials provided by the teacher, the objectives are not clearly delivered, and students needed to strictly follow up with the teacher to get all of the material. They stated, "using a course book would make it easy for us to study, and to revise for exams". The students indicated that they need the whole ELI approach to provide a clear description of the curriculum. Some students expressed their thoughts by saying, "at the beginning of the new year, it was confusing to get used to the new system, or to understand what was required to pass the course successfully."

Students suggested that the ELI reviews its policy regarding placing students into two levels; variations between students' levels in the same group impacted on the learning pace for good students. Likewise, several students commented that they were struggling in understanding the lesson content and following up with the teacher. Students displayed their dissatisfaction with long classroom hours, which negatively affected their motivation to learn English; they suggested that ELI implement a new policy of fewer contact hours, but with more efficient teaching instruction. They reflected, "not all English classes were beneficial--there were some useless activities". They also added, "because of the extended English teaching hours, we had no time to study other subjects". It is important to note that some students mentioned that although sometimes it is an advantage to be with a teacher for the whole semester, it could be a disadvantage if the teacher is less professional and their class is tedious. Some students also mentioned the demand of establishing a library on the campus where more resources are made available and easily accessible.

\section{Areas of Distinction in the New Curriculum}

There are areas that are used to organize the curriculum, and these areas led this curriculum seen to be distinctive in the eyes of the participants who were interested in expressing their ideas and thoughts. Answers are organized into three categories as follows:

Category 1: Teachers and quality of teaching. It includes thoughts on students' independence, motivation, thinking skills, self-directed learning, students' and teachers' autonomy, and instructional performance. Most students indicated their preference for teachers' instructional practices in terms of their roles in encouraging students to adopt a self-directed learning 
approach synchronized with learning in groups, simplifying content and abstractness. Such two systems pushed to initiate and take the risk to learn. As explained by Liu (2015), autonomy, which holds students' sense of responsibility toward their own learning of the target language, stands as a significant learner variable.

Students were satisfied with their experience in terms of pushing them to speak and present in English specifically when their teacher constantly uses the target language in and out of class. Teachers' freedom was an essential factor in promoting instructional creativity and providing sufficient space to deliver the curriculum's goals, illustrate, model, and role play content knowledge in an efficient way. Students think that when teachers used technology in their teaching, that made a distinctive aspect of the new curriculum.

With all such preference of certain noticed instructional practices, motivation is a significant factor contributing to success in second language learning. Many research conducted on L2 motivation emphasizes several techniques to energize it. As Dörnyei elaborated (2001), these techniques, which can be used by students, classmates, and even instructors, consciously influence goal-related behavior and positive perception towards second language learning.

Category 2: Program structure. It focuses on students' opinions and reflections on the distinctive areas on the structure of the course, timing and duration, and organization of the syllabus. The majority of responses agreed that skills were presented in a way that helped them to figure out their weakness and improve that area. The weekly syllabus was uncommonly organized in a skill-based model where each skill is assigned a fixed day. Such organization positively challenged students' persistence and deep comprehension of the importance of each skill which sounded appealing to their daily study routine. This semi- segregated-skill approach is considerably aligned with several studies that reached motivating findings. Summarized by ElKoumy (2004), ELKoumy (1999), Gambrell and Chasen (1991), and Leaman (1993), these studies indicated that direct instruction of language structures had enhanced the narrative writing skills among students of an average and below levels.

Additional studies by Abdan (1983) and Cooper (1981) concluded that direct instruction of sentence structure enhances students' writing performance. On the other hand, a blended approach of holistic and segregated-skill methods is more efficient model in enhancing learners' writing abilities than using one approach alone. At the same level, the combination of both the holistic approach and the segregated-skill approach can boost students' writing above the levels that occur with either alone. Such argument goes well with what Pressley (1998) elaborated,

Excellent classrooms involve a balancing of whole language experiences (e.g., reading of real texts, composition) and skills instruction. There is a good reason to suspect that classrooms that are either extremely skills-oriented or extremely anti-skills oriented (i.e., skills instruction occurs on an as-needed basis only in the context of reading and writing) are not as effective as more balanced classrooms". (p. 286).

Other features of distinction of the program structure included grade distribution, multi-tasks in every session, the demand of weekly presentations delivered by students, extensive reading 
comprehension, the inclusion of IELTS skills, and increased challenge with the positive absence of fixed textbooks.

Category 3: Content. It focuses on students' opinions and reflections on the distinctive areas on the course topics, themes, vocabulary, and general knowledge throughout the sessions. Topics covered throughout the course were authentic and led to the effective functional use of the target language. An increased interest nowadays in the integration of language and content to focus on developing language proficiency among through real-life themes and engaging content through meaningful literacy and discussion activities in L2 classes, consequently, making the course more understandable and sensible, and at the same time boosting students' academic language requirements. Defined by Ghee, Kee and Ismail (2012), EFL/ESL learners' motivation is highly connected with the goal of that learning. In other words, when students are sufficiently oriented to learn a second language, knowing that target language becomes highly motivated. Other features of distinctions in the new curriculum led students to express their opinion on the challenging vocabulary lists throughout the course, the intensive and extensive focus on functional knowledge structures, and age-appropriateness of topics and themes.

With the data-driven analysis in this paper, some crucial issues need reconsideration. Some presented findings raise questions about the reading content of curricula, and teaching methods in classrooms. Reading comprehension is considered a difficult skill for learners with limited vocabulary. That means reading materials need to be revised to check appropriateness level for the student's level of ability. It is also essential to check on how teachers teach reading, whether they implement different reading strategies to develop students' comprehension or that it is a sole focus on vocabulary memorization. In revisiting speaking abilities, listening skills need more emphasis. Listening activities increase students' understanding. As a result, the learners boost their abilities to speak and write. Students' disposition towards selecting and customizing specific learning strategies is another crucial aspect that needs more consideration. It is strongly impacted by some beliefs when it comes to learning a language. Learners have varied perceptions on what makes language learning practical and successful. More issues also appear related to the varied level of improvement among students. For example, unrealiable placement tests, previous high school syudies caused significant variations in the students' opinion. Other issues are related to the teaching and learning environment, such as the quality of teaching, and the campus on which the students were studying.

\section{Conclusion}

This exploratory study intends to look at how students enrolled at the foundation year program in tertiary education perceive the newly designed English curriculum and how their thoughts and reflections are valuable to revisit curriculum design principles in the context of Saudi tertiary education. The analysis in this paper attemts to manifest the differences and similarities in the viewpoints of participants. It also looks at how these viewpoints as guidelines for future enhancement of EFL curricula, and provides a profound understanding of a wellcontextualized language curriculum that puts great emphasis on culture, autonomy, motivation, and blended learning approaches, accordingly, demystifying teacher preparation programs and decentralized university programs. Such educational processes will hopefully lead language teachers, curriculum designers, and decision-makers in Saudi Arabia to manage the learning contexts better and promote efficient practices in language programs. 


\section{About the Author:}

Saeed Jameel Aburizaizah is a full time Associate Professor in Education and Applied Linguistics at King Abdulaziz University (KAU) with more than ten years of experience. Saeed holds a Master of Education in TESOL from the University of Exeter and Ph.D. in Education \& Applied linguistics from Newcastle University - UK. Saeed currently works as a Consultant to Vice-President for Graduate Studies and Scientific Research and Vice-President for Development at KAU. ORCID: https://orcid.org/0000-0002-0608-5194

\section{References}

Abdan, A. (1983). The effect of sentence-combining practice on the written syntactic maturity, overall writing quality, and reading comprehension of EFL Saudi students. Unpublished Ph.D. dissertation. The University of Kansas.

Aburizaizah, S. (2013). Developing a Framework for Classroom Lesson Delivery to Improve English Teachers' Performance in the Foundation Year Programme at a Saudi University. English Language Teaching, 7(1), 1-8. DOI:10.5539/ELT.v7n1p1

Amirian, S. M., \& Tavakoli, E. (2016). Academic oral presentation self-efficacy: a crosssectional interdisciplinary comparative study. Higher Education Research \& Development, 35(6). 1095 - 1110. DOI.org/10.1080/07294360.2016.1160874

Bandura, A. (1995). Exercise of personal and collective efficacy in changing societies. Cambridge University Press.

Barrett, N., Liu, G., \& Wang, H. (2020). Seamless learning for oral presentations: Designing for performance needs. Computer Assisted Language Learning, 1-26.

Brown, J. (1995). The elements of language curriculum: A systematic approach to program development. Boston: Heinle \& Heinle.

Cooper, T. (1981). Sentence combining: An experiment in teaching writing. Modern Language Journal, 65(2), 158-165.

Dionne, G., Dale, P. S., Boivin, M., \& Plomin, R. (2003). Genetic evidence for bidirectional effects of early lexical and grammatical development. Child Development, 74(2), 394412. DOI:10.1111/1467-8624.7402005.

Dörnyei, Z. (2001). Motivation strategies in the language classroom. Cambridge: Cambridge University Press.

ElKoumy, A. (1999). Effect of Instruction in Story Grammar on the Narrative Writing of EFL Students. Washington, D.C.: ERIC Clearinghouse on Languages and Linguistics. Available

at:https://www.academia.edu/3694861/Effect_of_Instruction_in_Story_Grammar_on_the arrative_Writing_of_EFL_StudentsSS\%20OPINIONS/Effect_of_Instruction_in_Story_G rammar_o.pdf

El-Koumy, A. (2004). Effect of the Holistic Approach on the Quantity and Quality of EAP Students' Writing. Education Resources Information Center (ERIC), USA 2004. Available at SSRN: https://ssrn.com/abstract=2365167.

Ellis, R. (2008). Learner beliefs and language learning. Asian EFL Journal, 10(4), 7-25.

Ellis, R. (2012). The study of second language acquisition (2nd ed.). Oxford: Oxford University Press. 
Ennis, R. (1990). The extent to which critical thinking is subject-specific: Further Clarification. Educational Researcher, 19(4), 13-16. DOI:10.3102/0013189X019004013

Finney, D. (2002). The ELT Curriculum: A Flexible Model for a Changing World. In J. Richards \& W. Renandya (Eds.), Methodology in Language Teaching: An Anthology of Current Practice (pp.69-79). Cambridge: Cambridge University Press. DOI:10.1017/CBO9780511667190.012.

Gambrell, L., \& Chasen, S. (1991). Explicit story structure instruction and the narrative writing of fourth, and fifth-grade below-average readers. Reading Research and Instruction, 31(1), 54-62. DOI.org/10.1080/19388079109558071

Gaudart, H. (1992). Persuading students to speak in English. In Wijasuria, B. and Gaudart, H. (Eds), Teaching and Learning English in Challenging Situations. Proceedings for the first Malaysian English Language Teaching Association International Conference.

Ghee, T.T., Kee, O.A., \& Ismail, H.N. (2012). The Orientation for Learning Mandarin amongst Malay Undergraduate Students. International Journal of Humanities and Social Science, 2(12), pp 104-112.

GĹ, Ăłwka, D. (2014). Studies in Second Language Learning and Teaching. Studies in Second Language Learning and Teaching, 4, 617-635. 10.14746/ssllt.2014.4.4.3. DOI.org/10.14746/ssllt.2014.4.4.3

Glasser, W. (1990). The quality school: Managing students without coercion. New York: Harper Collins.

Haynes, J. (2002). Children as philosophers: Learning through inquiry and dialogue in the primary classroom. London: Routledge Falmer.

Leaman, R. (1993). Effects of direct instruction of story grammar on story writing and reading comprehension of elementary school learning disabled students. In V. T.Rasinski, \& N. D. Padak, (Eds.), Inquiries in Literacy Learning and Instruction (pp.15-24). Newark, DE: International Reading Association.

Liu, H. (2015). Learner Autonomy: The Role of Motivation in Foreign Language Learning. Journal of Language Teaching and Research, 6, 1165-1174.

Long, M.H. (2005). Second Language Needs Analysis: Methodological issues in learner needs analysis. Cambridge University Press.

Macalister, J., \& Nation, I.S.P. (2019). Language Curriculum Design (2 ${ }^{\text {nd }}$ ed.). Routledge. DOI.org/10.4324/9780429203763.

Mahmud, M. (2018). Gender Differences in English language teaching. Asian EFL Journal Professional teaching articles, 20(5), 290-294 .

Nation, I. S. P. (1996). The four strands of a language course. TESOL in Context, 6(1), 7-12.

Ornstein, A. C., \& Hunkins, F. P. (2014). Curriculum foundations, principles and issues (6th ed.). Essex: Pearson Education.

Ortega, L. (2009). Understanding second language acquisition. London: Hodder Education.

Patterson, W. (2003). Breaking out of our boxes. Phi Delta Kappan, 84(8), 569-574.

Pressley, M. (1998). Reading Instruction That Works: The Case for Balanced Teaching. New York: Guilford Press.

Richards, J. C. (2013). Curriculum Approaches in Language Teaching: Forward, Central, and Backward Design. RELC Journal, 44(1), 5-33. DOI.org/10.1177/0033688212473293.

Shirkhani, S., \& Fahim, M. (2011) Enhancing Critical Thinking In Foreign Language Learners. Procedia - Social and Behavioral Sciences, 29, 111-115. 
Snyder, J., Bolin, F., \& Zumwalt, K. (1992). Curriculum implementation. In P. W. Jackson (Ed.), Handbook of research on curriculum (pp. 402-435). New York: Macmillan.

Sreena, S., \& Ilankumaran, M. (2018). Developing Productive Skills Through Receptive Skills - A Cognitive Approach. International Journal of Engineering and Technology, 7(4), 669-673. 10.14419/ijet.v7i4.36.24220.

Sulaiman, T., Ayub, A.F., \& Sulaiman, S. (2015). Curriculum Change in English Language Curriculum Advocates Higher Order Thinking Skills and Standards-Based Assessments in Malaysian Primary Schools. Mediterranean Journal of Social Sciences, 6(2), 494. 10.5901/MJSS.2015.V6N2P494.

Tanaka, K. (2012). Communicative Competence in the 21st Century: Issues in Japan's University English Language Education. Meiji Gakuin review International \& regional studies, (41), 21-36.

Swartz, R., \& Perkins, D. (1989). Teaching thinking: Issues and approaches. Pacific Grove, CA: Midwest Publications.

Wilson, J., \& Murdoch, K. (2008). Helping your pupils to think for themselves. London: Routledge.

Appendix A: Table 3. Pacing guide for week 1 - level 110

\begin{tabular}{|c|c|c|c|c|}
\hline \multicolumn{5}{|c|}{ Pacing Guide - Week 1} \\
\hline Level & \multicolumn{4}{|l|}{ ELI 110} \\
\hline Total class Hours & \multicolumn{4}{|l|}{18} \\
\hline $\begin{array}{l}\text { Online enriching } \\
\text { hours }\end{array}$ & \multicolumn{4}{|l|}{4} \\
\hline Target levels & \multicolumn{4}{|c|}{ CEFR (B1-B2) - CLB (6) - IELTS (4.5) } \\
\hline $\begin{array}{l}\text { Essential Thinking } \\
\text { Skill }\end{array}$ & \multicolumn{4}{|c|}{$\begin{array}{ll}\checkmark & \text { Making predictions } \\
\checkmark & \text { Activating prior knowledge }\end{array}$} \\
\hline Essential Study Skill & \multicolumn{4}{|c|}{$\begin{array}{ll}\checkmark & \text { Skimming and scanning } \\
\checkmark & \text { Mind-Mapping } \\
\checkmark & \text { Note-taking }\end{array}$} \\
\hline $\begin{array}{l}\text { Essential } \\
\text { Presentation Skill }\end{array}$ & \multicolumn{4}{|l|}{$\begin{array}{ll}\checkmark & \text { Using proper voice tone. } \\
\checkmark & \text { Using proper posture. }\end{array}$} \\
\hline Theme & \multicolumn{4}{|l|}{ Community } \\
\hline Topic & \multicolumn{4}{|l|}{ Rules Around the World } \\
\hline Material & \multicolumn{4}{|c|}{ Available on ELI E-Inventory \& extra materials as provided by the instructor } \\
\hline Vocabulary list & $\begin{array}{ll}\text { 1. } & \text { Relax (relax the rules) } \\
\text { 2. } & \text { Compulsory } \\
\text { 3. } & \text { Recommend } \\
\text { 4. Especially } \\
\text { 5. Competent } \\
\text { 6. Appropriately }\end{array}$ & $\begin{array}{ll}\text { 7. } & \text { Respect } \\
\text { 8. } & \text { Awkward } \\
\text { 9. } & \text { Elderly } \\
\text { 10. Rude } \\
\text { 11. Rule(s) (n.) } \\
\text { 12. Civilized } \\
\text { 13. } \text { Thorough }\end{array}$ & $\begin{array}{l}\text { 14. Convert } \\
\text { 15. Implement } \\
\text { 16. Trial } \\
\text { 17. Manners } \\
\text { 18. Behavior } \\
\text { 19. Etiquette }\end{array}$ & $\begin{array}{l}\text { 20. Actually } \\
\text { 21. Dangerous } \\
\text { 22. Enough } \\
\text { 23. License } \\
\text { 24. Gestures } \\
\text { 25. } \text { Block (v.) }\end{array}$ \\
\hline \multicolumn{5}{|c|}{ Main SLOs } \\
\hline \multicolumn{5}{|c|}{$\begin{array}{l}\text { By the end of this week, students can } \\
\text { - } \quad \text { Make predictions about content related to "Rules around the World." } \\
\text { - } \quad \text { Connect prior knowledge to their predictions. } \\
\text { - } \quad \text { Find key information from a specific content (recording, passage) related to "Rules around the World." }\end{array}$} \\
\hline
\end{tabular}


- Use verbs of compulsion and prohibition in meaningful contexts.

- Ask WH-Questions in meaningful contexts.

- Use suffixes that change verbs into nouns in meaningful contexts.

- Use listed vocabulary in meaningful contexts and sentences.

- Write an outline of home/family rules.

- Interview a classmate and present home/family rules to the class.

\begin{tabular}{|c|c|}
\hline \multicolumn{2}{|r|}{ Weekly Plan - 1} \\
\hline $\begin{array}{l}\text { Skill / } \\
\text { language }\end{array}$ & Specific SLOs \\
\hline $\begin{array}{l}\text { Sunday } \\
\text { Grammar \& } \\
\text { Vocabulary }\end{array}$ & $\begin{array}{l}\text { - Use verbs of compulsion and prohibition in meaningful sentences and contexts: } \\
\text { Make-stop-keep-prevent-encourage-discourage-expect. } \\
\text { - } \quad \text { Ask WH-Questions in meaningful contexts: (who, what, when, where, why) } \\
\text { - } \quad \text { Use suffixes that change verbs into nouns in meaningful contexts. } \\
\text { - } \quad \text { Use listed vocabulary for the week in meaningful sentences, and contexts. } \\
\text { - } \quad \text { Identify parts of speech. }\end{array}$ \\
\hline $\begin{array}{l}\text { Monday } \\
\text { Listening }\end{array}$ & $\begin{array}{l}\text { - Make predictions about a listening text related to "Rules around the World" based on prior } \\
\text { knowledge, supporting visuals and other cues. } \\
\text { - Identify key information about the text through skimming and scanning. } \\
\text { - Identify the primary genre or type of a listening text. }\end{array}$ \\
\hline $\begin{array}{l}\text { Tuesday } \\
\text { Reading }\end{array}$ & $\begin{array}{l}\text { - Make predictions about a reading text on "Rules around the World" based on prior } \\
\text { knowledge, supporting visuals and other cues. } \\
\text { - } \quad \text { Find key information in a reading text using skimming and scanning strategies. }\end{array}$ \\
\hline $\begin{array}{l}\text { Wednesday } \\
\text { writing }\end{array}$ & $\begin{array}{l}\text { - Map a visual outline of home/family rules. } \\
\text { - Write an outline of home/family rules using verbs of compulsion and prohibition, and } \\
\text { - } \quad \text { Usoper nouns. (6 Rules only). } \\
\text { - } \quad \text { Employ proper rules of spelling, capitalization, and punctuation. } \\
\text { Instructions for Instructors: } \\
\text { - } \quad \text { The instructor provides a model outline/mind-map. } \\
\text { - } \quad \text { Students brainstorm ideas on mind map and the instructor gives instant feedback. } \\
\text { - } \quad \text { Main task (equals } 5 \text { points): students produce the first draft of writing an "outline" of own } \\
\text { home/family rules. The instructor gives instant feedback. } \\
\text { At home, students edit and rewrite their work based on the instructor's feedback and } \\
\text { - } \quad \text { Instructors score students' written pieces and hand them to students during the next class. } \\
\text { - Students compile their work in their portfolios. } \\
\text { Scanned copies of scored work should be kept with the instructor. }\end{array}$ \\
\hline $\begin{array}{l}\text { Thursday } \\
\text { Speaking }\end{array}$ & $\begin{array}{l}\text { - In pairs, interview a classmate to find out key information about home/family rules through } \\
\text { using WH-questions ( } 3 \text { questions only per student). } \\
\text { - Take notes on classmate's answers. } \\
\text { - } \quad \text { Give a brief presentation to introduce a classmate's home/family rules. (2 rules only per } \\
\text { student). } \\
\text { - } \quad \text { Use proper tone and posture during presentation. } \\
\text { Instructions for Instructors: } \\
\text { - } \quad \text { The instructor divides students into pairs. } \\
\text { - } \quad \text { The instructor provides sample interview questions. } \\
\text { - } \quad \text { Students brainstorm interview questions on worksheets. } \\
\text { - } \quad \text { The instructor gives instant feedback. } \\
\text { - } \quad \text { Main Task (equals } 5 \text { points): Students present their classmate's answers and the instructor } \\
\text { scores their presentations using a scaled checklist. } \\
\text { - Scored sheets are kept with the instructor till next week. } \\
\text { - Students should compile their work in their Portfolios. } \\
\text { Scanned copies of scored work should be kept with instructor. }\end{array}$ \\
\hline
\end{tabular}

Appendix A: Table 4. Pacing guide for week 8- level 120 
Arab World English Journal (AWEJ) Volume 12. Number 4. December 2021

A Need for a Substantive Change in Tertiary EFL Education

Aburizaizah

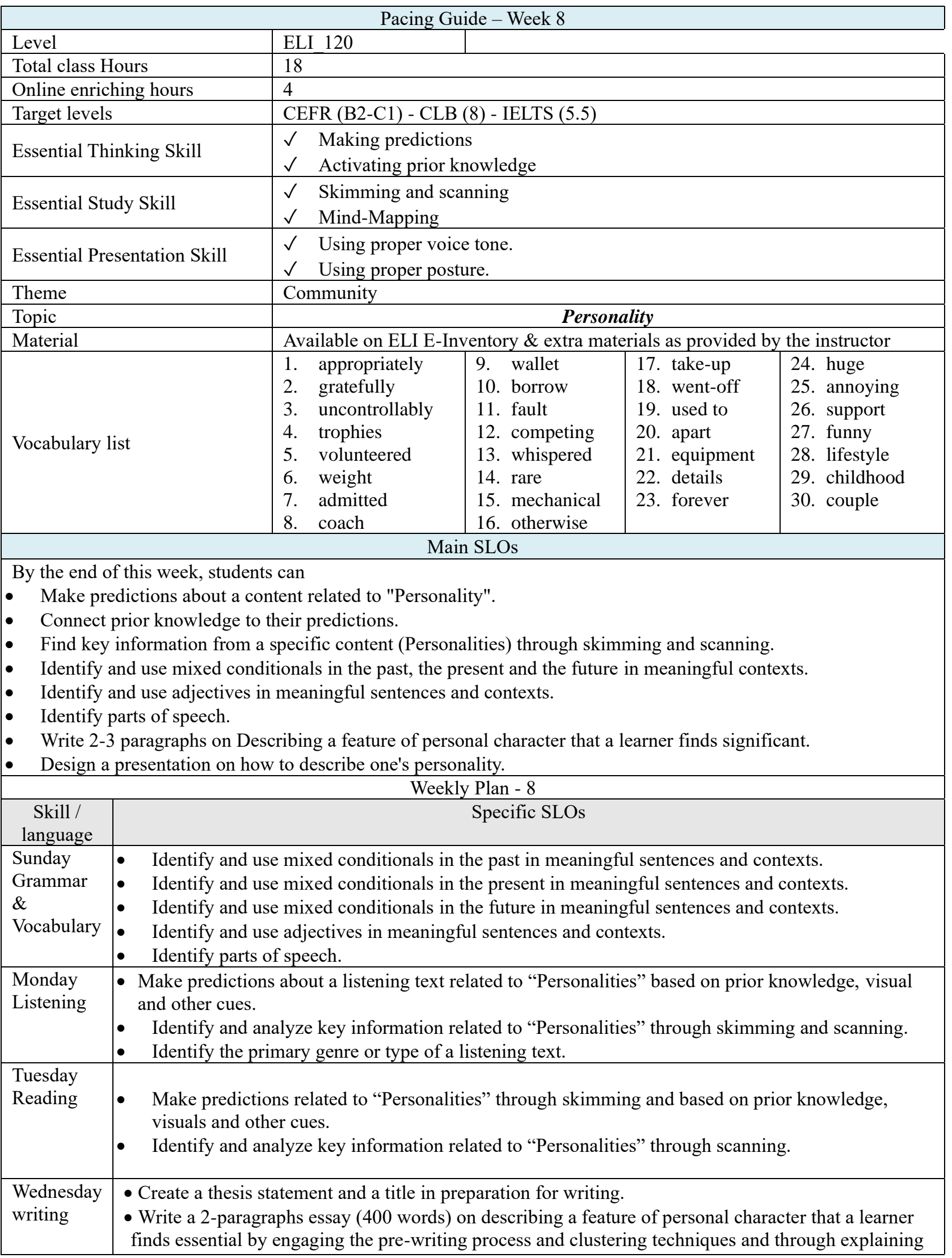




\begin{tabular}{|c|c|}
\hline & $\begin{array}{l}\text { the following: } \\
\text { What is it? } \\
\text { Is it a common characteristics? } \\
\text { Why it is important? } \\
\text { How does this characteristic lead to success in life? } \\
\text { - } \quad \text { Understand and identify what plagiarism is and how to avoid it. } \\
\text { Employ necessary grammatical patterns and vocabulary of the week. } \\
\text { Employ proper rules of spelling, capitalization and punctuation. } \\
\text { Instructions for Instructors: } \\
\text { - } \quad \text { The instructor provides samples of an essay to students. } \\
\text { - } \quad \text { As an alternative, students can use their mobile devices to search for information and supporting } \\
\text { ideas keeping in mind plagiarism concepts. } \\
\text { - } \quad \text { Main task (equals } 5 \text { points): students produce the second draft of their writing and the instructor } \\
\text { gives instant feedback. } \\
\text { At home, students edit and rewrite their work based on instructor's feedback and upload/send their } \\
\text { final drafts. } \\
\text { The instructor scores students' written pieces and hands them to students in the next class. } \\
\text { - Students compile their work in their portfolios. } \\
\text { Scanned copies of scored work should be kept with the instructor. }\end{array}$ \\
\hline $\begin{array}{l}\text { Thursday } \\
\text { Speaking }\end{array}$ & $\begin{array}{l}\text { - Present information answering the following questions: } \\
\text { - How would you describe yourself? } \\
\text { - } \quad \text { Are you similar or different to your brother(s)/sister(s)? } \\
\text { - Use proper tone and posture during presentation. } \\
\text { Instructions for Instructors: } \\
\text { - } \quad \text { The instructor provides a sample description. } \\
\text { - } \quad \text { Main task (equals } 5 \text { points): students present their ideas, and the instructor scores their } \\
\text { - } \quad \text { presentations using a scaled checklist. } \\
\text { - } \quad \text { Students should compile their work in their portfolios. } \\
\text { - } \quad \text { Scanned copies of scored work should be kept with the instructor. }\end{array}$ \\
\hline
\end{tabular}

